\title{
The impact of intangibles on the value relevance of accounting information: Evidence from French companies
}

\author{
Bilal Kimouche ${ }^{1}$, Abdenacer Rouabhi ${ }^{2}$ \\ ${ }^{1}$ University of Skikda (Algeria) \\ ${ }^{2}$ University of Setif 01 (Algeria) \\ kimouchebilal@ymail.com,_abrouabbi2005dz@yaboo.fr
}

Received May, 2015

Accepted February, 2016

\section{Abstract}

Purpose: The paper aims to explore whether intangible items that recognised in financial statements are value relevant to investors in the French context, and whether these items affect the value relevance of accounting information.

Design/methodology: The data has been collected from a sample of French listed companies over the nine year period of 2005 to 2013. Starting of Ohlson's (1995) model, the Correlation analysis and the Linear Multiple Regression has been applied.

Findings: We find that intangibles and traditional accounting measures as a whole are value relevant. However, the amortization and impairment charges of intangibles and, cash flows do not affect the market values of French companies, unlike other variables, which affect positively and substantially the market values. Also goodwill and book values are more associated with market values than intangible assets and earnings respectively. Finally, we find that intangibles improve the value relevance of accounting information.

Practical implications: French legislators must give more interest to intangibles, in order to enrich the content of financial statements and increase the pertinence of accounting 
information. Auditors must give more attention to intangibles' examination process, in order to certify the amounts related to them in financial statements, and hence enrich their reliability, what provides adequacy guarantees for investors to use them in decision making.

Originality/value: The paper used recently available financial data, and proposed an improvement concerning the measure of incremental value relevance of intangible items.

Keywords: Relative value relevance, Incremental value relevance, Intangible items, Traditional accounting measures, Equity valuation, French listed companies

Jel Codes: M40, M41

\section{Introduction and background}

The purpose of financial accounting is to satisfy the users' needs of financial information that is helpful in decision making. Therefore, managers prepare and present financial statements, which represent the main source of information. According to IASB (1989), the objective of financial statements is to provide useful information about financial position, performance and changes in financial position of a firm. The usefulness of accounting information have been constantly expressed in the literature by the term "value relevance", which measures the utility of accounting figures from the perspective of equity valuation (Beisland, 2009). Watts and Zimmerman (1990) described this concept as "information perspective", which views financial statements as a provider of information for the valuation models.

The value relevance reflects the main function of accounting, which relates to the supplying of useful information that enables investors to value securities and make rational decisions (Dumontier \& Labelle, 1998). The objective of value relevance research is to relate financial statement figures to a measure of firm's value and, to assess the relation of such information to the determination of value (Dahmash \& Qabajeh, 2012). The value relevance measures the ability of financial statements to capture and summarize information that is reflected in firm's value (Francis \& Schipper, 1999). Under this concept, to be value relevant, accounting information must be associated with the current company value.

The value relevance measures have been interpreted as the total market share, among all information impounded in stock price, attributable to accounting information (Balachandran \& Mohanram, 2011). 
This means that accounting information be relevant when they reflect information used by investors to appreciate the firm's value. According to Lam, Sami and Zhou (2013), the higher the value relevance, the more financial statements can be relied upon to make investment decisions and thus the greater the association between financial statement items and firm market values. Finally, the value relevance interests by determining whether accounting information can explain market values, through studding the association between financial statements figures and market values over a long period, in order to measure the power of these figures to explain market values.

Lev (1989) found that most studies concerned by the value relevance of intangibles reported a remarkably low statistical association between stock returns and current earnings. The explanatory power as measured by $\mathrm{R}^{2}$ was often below $10 \%$, it approached from zero in some cases. During the two last decades, several studies indicated that the association between market values and accounting has declined and accounting information has lost their value relevance over time (Lev \& Zarowin, 1999; Brown, Lo \& Lys, 1999; Graham, King \& Bailes, 2000; Black \& White, 2003; Dontoh, Radhakrishnan \& Ronen, 2007). However, other studies found a decrease in value relevance of earnings replaced by an increase in value relevance of equity's book values (Collins, Maydew \& Weiss, 1997; Francis \& Schipper, 1999; Ely \& Waymire, 1999; Hail, 2013; Lam et al., 2013). This means that earnings and equity's book values do not affect stock prices in the same manner; there are some differences between the two parameters over time, either for different industries or different countries (Glezakos, Mylonakis \& Kafouros, 2012). Another group of studies showed a change in different directions when different accounting items are used (Gjerde, Knivsflå \& Sættem, 2011; Chalmers, Clinch \& Godfrey, 2011).

Several researchers have indicated the gap between market values and equity's book values of firms as a result of the decreasing value relevance of accounting information. Cañibano, García-Ayuso and Sánchez (2000) suggested that this gap represents not only a revolutionary change in the process of value creation, but also a declining value relevance of traditional financial measures. Francis and Schipper (1999) concluded that such phenomenon might result either because accounting practices have remained stagnant while business has changed, or because accounting practices have changed in ways that diverge from providing value relevance information. According to Lev and Zarowin (1999), the declining value relevance of accounting information was mainly caused by the increasing pace of change affecting business, and the inadequacy of accounting system to reflect this change. In this context, intangible elements represent changes driver or changes produce. Since the economy has shifted from one based on tangible assets and manufacturing to one increasingly based on intangible 
assets, services and information, accounting has not kept up with these changes (Landsman \& Maydew, 2001).

To be useful and, hence value relevant, financial information must not represent only relevant phenomena, it must also faithfully represent the phenomena that it purports to represent (Nayeri, Ghayoumi \& Bidari 2012; Karğın, 2013). As mentioned by Barth, Beaver and Landsman (2001), the value relevance is not a stated criterion of IASB; it is in fact the operationalizing of all qualitative characteristics of financial statements. However, the traditional accounting model oriented toward the past has become incapable to reflect the progressive economic transformations. The value relevance claims that any event likely to affect firm's current financial position or its future performance should be reported in its annual accounts, but that is not the case for intangibles, which are partially recognised in financial statements. The accounting criteria for recognition and measurement do not allow reporting the most part of intangibles. As result, accounting information is reliable but not relevant to assess the firm's value, what affects positively the gap between equity's market values and its book values, without taking into consideration the other factors (Eckstein, 2004; Skinner, 2008; Jaafar, 2010; Zéghal \& Maaloul, 2011).

Today's economy is driven primarily by the creation and manipulation of intangibles (Lev, 2001), that are a key factor for development and success of organizations competing in the economic and technological context (Córcoles, 2010). From a managerial approach, «Resources-Based View» considers that intangibles represent strategic assets that give competitive advantages for firms and sustain them. While from an economic approach, intangibles have become the main instigator of value creation and growth (Daum, 2003; Cohen, 2005; Moore \& Craig, 2008). Consequently, IASB has worked hardly to develop guidelines for identification, recognition and measurement of intangible assets, and some directions for their disclosure, in order to improve financial statements content.

From analysis of standards published since the early of 80 's, it arises that IASB attempts to adapt financial statements with economic evolutions. Following IAS 38, firms must recognise all intangible assets arising from development activities if the determined conditions have been fulfilled (IASB, 2004). IASB insists facilitating the recognition and reporting of intangible assets separately from goodwill. According to IFRS 3, all identifiable intangible assets acquired in a combination must be recognised separately, and recorded with their fair values if they can be measured reliably. It is the same manner for all intangible assets identifiable jointly or with related contract, identifiable asset or liability. The revised standard requires recognising all tangible and intangible $R \& D$ assets acquired in a business 
combination if they have an alternative future uses (IASB, 2008). Concerning goodwill, IAS 38 imposes its impairment unlike several known practices that impose amortizing it over its useful life.

For many decades, French companies have been considered among the pioneers in creation and manipulation of intangibles, thence French economy has become an important source of competitiveness and wealth generation. According to the Wolrd Bank (2006), France has been considered among the top ten countries regarding the contribution of intangibles in wealth. Fustec (2011) documented that accounting and extra-accounting goodwill represent the major part of French companies' value, it reached around $55 \%$ and $72 \%$ from the CAC 40 index during the period of 2005 to 2011, whether in the crisis period or not. For the SMEs, goodwill is very important since it represents two thirds of the total companies' value. To reflect those transformations, French legislator has updated repeatedly the accounting rules and practices that allowed to prepare and presenting financial statements. Since 2005, French accounting practices have known a revolutionary change, when listed companies apply IFRS via EU adoption and implementation process. In France, IFRS has been mandatory in consolidated financial statements of listed companies, permitted in consolidated financial statements of non-listed companies and prohibited in separated financial statements.

The main purpose of this paper is to investigate the role of intangibles in the valuation of French companies. Our problematic consists examining the impact of intangible items recognised in financial statements on the value relevance of accounting information. This impact has been referred in the literature under the term "incremental value relevance". For that, the common value relevance of intangibles and traditional accounting items, and the separate value relevance of each above have been measured. The paper is structured as follows; section 2 present the literature review; section 3 lights the research design and methods used to collect and examining the data; while the empirical results are described and discussed in section 4. Finally, section 5 summarizes the conclusions.

\section{Literature Review}

The intangibles' value relevance studies have known an important interest since the early of 90's. Sougiannis (1994) concluded that investors place a high value on intangible investments; he estimated that on average, a one-dollar increase in $\mathrm{R} \& \mathrm{D}$ expenditures produces a five-dollar increase in market value. He distinguished between the indirect effect, when $\mathrm{R} \& \mathrm{D}$ expenditures affect market values through earnings, and the direct effect that reflects new information conveyed by R\&D. He assessed also that on average the indirect effect is more than the direct effect. Aboody and Lev (1998) found 
that capitalized software amounts summarize relevant information; they associate with market variables and future earnings.

Seethamraju (2003) showed significant abnormal returns related to brands capitalized as a part of businesses combination. He observed abnormal returns with companies that reported quantitative information more than those that reported only qualitative information. Goodwin and Ahmed (2006) confirmed the indirect effect of intangibles on market values; they found that intangible assets increase the value relevance of earnings. Zhao (2002) showed that the reporting of total R\&D costs increases the association of stock price with accounting earnings and book values in countries with complete $R \& D$ expensing. The allocation of $R \& D$ costs between capitalization and expense provides incremental content over that of total $\mathrm{R} \& \mathrm{D}$ costs in countries permitting conditional capitalization of $\mathrm{R} \& \mathrm{D}$ costs.

In France, the early studies about the value relevance of intangibles concerned by the R\&D, but the results were partially supported those that found in USA. Ding and Stolowy (2003) tested whether the $\mathrm{R} \& \mathrm{D}$ capitalization improves the value relevance of accounting numbers. They did not find any positive results in this direction, what reflects the particularities of financial disclosure in French, and the differences between French and Anglo-American's corporate governance model. From a sample of 95 French companies during 1998 to 2000, Cazavan-Jeny and Jeanjean (2003) found a positive association of capitalized R\&D with stock prices and returns, and negative association of expensed $R \& D$ with stock prices and returns. This means that $R \& D$ accounting represents a signal reduces the information asymmetry about R\&D projects. Loulou and Triki (2008) denoted that activated R\&D constitutes preferred treatment for managers, not only to signal the investors about the future perspectives of their $\mathrm{R} \& \mathrm{D}$ programs, but also to respond opportunely to the contractual stakes, in order to minimize political costs or smoothing earnings.

Thibierge (2001) interested by intangible assets as a stake of financial reporting, by studying 176 French companies and 85 Spanish companies that listed in 1999 or 2000. The results indicated that intangible assets did not affect the companies' market valuation, but they permit liberating from liquidity or debt covenants, there are important differences between both countries. Cazavan-Jeny (2003) concerned by the significant gap between market values and book values of French companies. Using a sample of 470 companies, during 1994 to 1999, he examined whether this gap can be attributed to the fact that intangible assets are not reflected in financial statements. The results indicated a significant statistical association of market-to-book ratio with capitalized goodwill. However, any significant statistical link has been observed neither with other capitalized intangibles nor with expensed intangibles. Those 
results have been explained by the multitude of accounting treatments concerning intangible expenditures.

Using a sample of companies that listed in some European financial markets (UK, France and Spain) during 1993 to 2003, Casta and Ramond (2005) did not find any association between intangibles and market returns. They suggested that investors have a short-term view or "myopic" in constructing of their portfolio, what penalizes companies that reported high intangible investments in their financial statements, which have a long-term view. In order to test the role of intangibles in improving firm's value, Jamoussi, Baklouti and Affes (2007) used a sample of 391 French listed companies during 2001 to 2004. The results have confirmed the importance of earnings per share and intangibles for companies' valuation. However, they showed a significant decreasing value relevance of traditional accounting information for the high technology companies' valuation, while the intangibles have affected positively and significantly the market values of those companies.

Lenormand and Touchais (2008) asked question about the role of IFRS adoption in improving the informational content of intangible assets. After reviewing previous studies, they concluded that IFRS adoption does indeed improve the informational content of accounting measures. Nevertheless, the data analysis showed significant disparity between the reported amounts of goodwill and intangible assets under different standards. It arises that intangible assets are only partially more value relevant under IFRS. Boulerne and Sahut (2009) tested the information content of intangible assets under IFRS when compared with local GAAP for French listed companies. They showed that the transition to IFRS did not affect the overall amounts of intangibles, even though it operated substitution effects in favor of goodwill. However, the total amounts of intangible assets and goodwill together was value relevant under IFRS. They implied that financial markets can better integrate such contributions into share prices and returns, especially for companies with high intensity of intangible assets.

For the same precedent objectives, Sahut, Boulerne and Frédéric (2011) compared the value relevance of intangible assets under IFRS with local GAAP for European listed companies; their sample included 1855 companies for ten European countries. The study has been carried out over six-year period, from 2002 to 2004 for local GAAP, and from 2005 to 2007 for IFRS. The results tend to confirm partly the findings of Boulerne and Sahut (2009). It arises that book values of identifiable intangible assets were higher and have more informative value to explain share prices and stock returns under IFRS than local European GAAP. However, goodwill has less value relevance under IFRS than local European GAAP. Exception of Italy and Finland, the identifiable intangible assets provided more value relevance information than intangible assets that have been transferred into goodwill. 


\section{Research design}

\subsection{Model specification}

We based on Ohlson (1995), which expressed the firm's market value as a linear function of its book value and abnormal earnings with other relevant information. Our research design included three models take the form of Linear Multiple Regression. Initially, we focused on model (1) to test the value relevance of traditional accounting measures, which expressed by the book values of equity before intangible items $\left(B V_{-} I N\right)$, earnings before amortization and impairment charges of intangibles $\left(E \_A I C\right)$, and controlled by cash flows $(C F)$.

$$
P_{i t}=\alpha_{0}+\alpha_{1} B V_{-} I N_{i t}+\alpha_{2} E_{-} A I C_{i t}+\alpha_{3} C F_{i t}+\varepsilon_{i t}
$$

Where $P_{i t}$ is the market value of company, measured by the firm's stock price four months after fiscal year-end; $B V \_I N_{i t}$ is the book value of equity per share at year-end after subtracting intangible assets per share and goodwill per share, it represents the book value of equity if any intangible item did not recognized in balance sheet. $E \_A I C_{i t}$ is the earning per share at year-end after adding amortization and impairment charges of intangibles per share, it represents the earning if any amount of intangibles' amortization and impairment charges did not recognized in income statement. $C F_{i t}$ is the free cash flows at year-end; it includes the operating, investment and financial activities during the year. $\alpha_{0}$ is a constant that represents the firm's market value, when all traditional accounting measures take the value zero. $\alpha_{1}, \alpha_{2}, \alpha_{3}$ are constants used to test the relationships between market values and traditional accounting measures. $\varepsilon_{i t}$ is the part of market values that cannot be interpreted by the traditional accounting measures (residuals). To measure the value relevance of traditional accounting measures, we used the coefficient of determination $\left(R^{2}{ }_{T A M}\right)$ of model (1), which expresses the volatility of market values that can be explained by traditional accounting measures.

Secondly, we tested the value relevance of intangible items using model (2); intangible items have been expressed by intangible assets $(I A)$, goodwill $(G W)$ and the amortization and impairment charges of intangibles $(A I C)$.

$$
P_{i t}=\beta_{0}+\beta_{1} I A_{i t}+\beta_{2} G W_{i t}+\beta_{3} A I C_{i t}+\mu_{i t}
$$

Where $L A_{i t}$ is the net amount of intangible asset per share at year-end that recognised separately from goodwill, $G W_{i t}$ is the net amount of goodwill per share at year-end that arisen from business combinations and recognised in balance sheet separately from other fixed assets. Our sample indicated that the most companies have already recognised amounts of goodwill (more than $92 \%$ of 
observations), for the companies that amortized or impaired goodwill completely, or that have never engaged in a business combination, goodwill takes the value zero. $A I C_{i t}$ is the amortization and impairment charges of intangible assets and goodwill per share in the year. $\beta_{0}$ is an estimate of market value when all intangible items in the balance sheets take the value zero. $\beta_{1}, \beta_{2}, \beta_{3}$ are constants used to test the associations between market values and intangible items. $\mu_{\mathrm{it}}$ is the part of market values that is not explained by intangibles. The value relevance of intangible items has been measured by the coefficient of determination $\left(R_{I N}^{2}\right)$ of model (2), which measures the volatility of market values that can be explained by intangible items.

Thirdly, we tested the common value relevance of both traditional accounting measures and intangible items, by adding the intangible variables to the traditional accounting variables, as shown in model (3).

$$
P_{i t}=\delta_{0}+\delta_{1} B V_{i t}+\delta_{2} E_{i t}+\delta_{3} C F_{i t}+\delta_{4} L A_{i t}+\delta_{5} G W_{i t}+\delta_{6} A I C_{i t}+3_{i t}
$$

Where $B V_{i t}$ is the book value of equity per share at year-end, $E_{i t}$ is the earning per share at year-end. In model (3), book values of equity and earnings represent the traditional accounting measures after intangibles; the book values include intangible assets and goodwill, while the earnings include amortization and impairment charges of intangibles. $\delta_{0}$ is an estimate of market value when all traditional accounting measures and intangible items take the value zero. $\delta_{1}, \delta_{2}, \delta_{3}, \delta_{4}, \delta_{5}, \delta_{6}$ are constants used to test the associations between market values and accounting variables. The common value relevance of both traditional accounting measures and intangibles has been measured by the coefficient of determination $\left(R_{T A M, I N}^{2}\right)$ of model (3), which expresses the volatility of market values that can be assigned to independent variables of model (3).

Finally, as presented in equation (4), we measured the incremental value relevance of intangible items $\left(R_{I N \mid T A M}^{2}\right.$, by comparing the common value relevance of both traditional accounting measures and intangible items $\left(R_{\text {TAM,IN }}^{2}\right)$ with the value relevance of traditional accounting measures $\left(R_{\text {TAM }}^{2}\right.$. The incremental value relevance of intangibles represents the increase in value relevance of traditional accounting measures caused by intangibles, after adding intangible assets and goodwill to book values, integrating amortization and impairment charges of intangibles in earnings and making intangible items as independent variables with traditional accounting measures in model (3).

$$
R_{I N \mid T A M}^{2}=R_{T A M, I N}^{2}-R_{T A M}^{2}
$$




\subsection{Sample and data collection}

The study has been carried out using a sample of French listed companies, during a period of nine years (2005 to 2013), after the IFRS mandatory adoption by EU's listed companies. Starting of Euronext data base, a sample of 186 non-financial companies has been randomly selected and, the data that concern their stock prices has been obtained. However, the data that concern independent variables has been collected from financial statement available at the electronic sites of companies. They have been completed from the financial data offered at www.zonebourse.com. The data selection process generated a sample of 1359 firm-year observations, after excluding all observations with incomplete data and eliminating all companies that are not listed over all the period.

Figure 1 illustrates the part of intangibles in market value of French companies over the period of study, which resembles with the allocation of market value of CAC 40 companies by Lasteyrie (2011). It seems clearly that intangibles constitute an important part of market value of French companies over the whole period, almost $31 \%$ for goodwill and $15 \%$ for intangible assets. These preliminary results confirm the results of the investigation realized by ERNST \& YOUNG (2008), which showed that intangibles represent more than $63 \%$ from the market values of European listed companies. As illustrated In Figure 1, the parts of intangible assets and goodwill in market value of French companies reached almost $28 \%$ and $13 \%$ respectively in 2005. It saw a little decrease in 2006 and 2007 when it achieved its lower levels during the period (22\% and $11 \%$ respectively). In 2008, a marked increase in the parts of intangibles in market value has happened and continued in 2009, when they attained their higher levels during the period of study (46\% for goodwill and $24 \%$ for intangible assets). The period after 2009 has known a little decrease in the parts of intangibles in market value of French companies.

The accounting data collected from financial statements of studied French companies that presented in Figure 1 reflects the rising interest given to intangibles by standard setters and managers during the last two decades; what affects positively the part of intangibles in financial statements, which have known a remarkable increase between the beginning and the end of the period of study. On the contrary, the part of other assets and liabilities recognised in the balance sheets has known a decrease during the period of study; it attained $37 \%$ at the beginning of the period and $28 \%$ at the end. The third part of market values in Figure 1 relates to the gap between market and book value of French companies. This gap reflects different internal and external factors related to companies, like assets and events that are not recognised in financial statements, because they do not meet the conditions and criteria of recognition, or they are not reliably measurable. Several intangible elements (e.g. knowledge, 
information, technology, innovation, research, competencies, competitive advantages and relations... etc.) have been considered among the main factors affecting this gap.

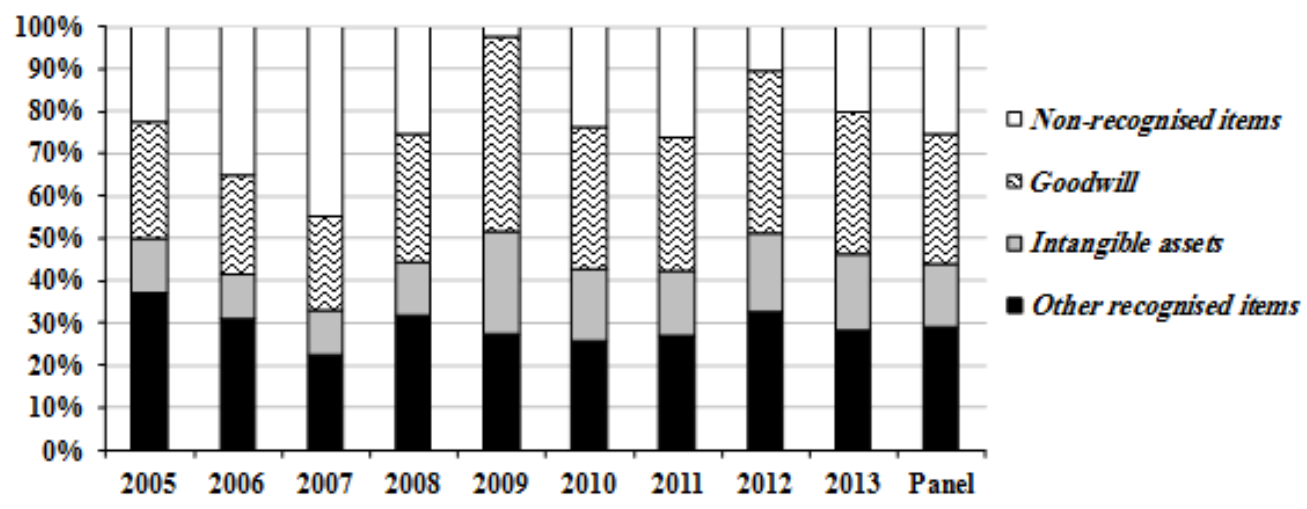

Figure 1. Intangibles and market value of companies: (Euronext, 2005-2013)

In order to attain more accurate results, by reaching the normality of data for each variable and ensuring the normality of residuals, we converted all above figures into their natural logarithmic counterparts (Glezakos et al., 2012). As shown in Table 1, the number of observations has attained 1354; it concerns 154 companies over nine years (2005 to 2013). The conversion of variables to their natural logarithmic has permitted to reduce the dispersion of data. When we observe standard deviation, we find that earnings before amortization and impairment charges of intangibles $L n\left(E \_\right.$AIC $)$ are more dispersal than other variables and have the biggest range (Max - Min $=66.73$ ), while market values $\operatorname{Ln}(P)$ are the less dispersal, and have the smallest range $(\mathrm{Max}-\mathrm{Min}=6.95)$. The dispersions and the ranges of other variables are approximates (between 10.57 and 15.82 for the ranges). Finally, we observe that the means and the medians are approximates for all variables, there are small differences between the two above measures.

\begin{tabular}{|l|r|r|r|r|r|r|r|}
\cline { 2 - 8 } \multicolumn{1}{c|}{} & \multicolumn{1}{c|}{ Obs. } & \multicolumn{1}{c|}{ Min } & \multicolumn{1}{c|}{ Max } & \multicolumn{1}{c|}{ Sum } & Mean & Median & Std. Dev. \\
\hline Ln(P) & 1354 & -1.66 & 5.29 & 3820.34 & 2.82 & 3.04 & 1.25 \\
\hline Ln(BV) & 1354 & -2.51 & 5.90 & 3225.23 & 2.42 & 2.67 & 1.34 \\
\hline Ln(E) & 1354 & -6.62 & 3.95 & 392.19 & 0.34 & 0.58 & 1.42 \\
\hline Ln(CF) & 1354 & -8.95 & 4.22 & -366.07 & -0.44 & -0.25 & 1.79 \\
\hline Ln(IA) & 1354 & -10.82 & 5.00 & -333.45 & -025 & 0.07 & 2.28 \\
\hline Ln(GW) & 1354 & -7.78 & 5.46 & 1585.57 & 1.31 & 1.66 & 1.78 \\
\hline Ln(AIC) & 1354 & -10.82 & 2.86 & -2300.33 & -1.74 & -1.48 & 1.91 \\
\hline Ln(BV_IN) & 1354 & -4.92 & 5.90 & 1722.19 & 1.73 & 1.83 & 1.58 \\
\hline Ln(E_AIC) & 1354 & -14.49 & 52.24 & 3990.23 & 2.95 & 1.80 & 4.57 \\
\hline
\end{tabular}

Ln: is the natural logarithmic

Table 1. Descriptive statistic of panel data 
To test the value relevance and the incremental value relevance of intangibles, we estimated the regression coefficients for each model $(\alpha, \beta, \delta)$, using Ordinary Least-Squares $(O L S)$ and tested them using Student test $(t)$. The signification of models has been tested by F-statistics (F-stat.). In order to verify the OLS's criteria, we used Kolmogorov-Smirnov and Shapiro-Wilk for the Data normality test, Durbin-Watson to test the Independence of residuals, Goldfield-Quandt to test the Homoscedasticity of residuals and Variance inflation factor $(V I F)$ to test the Multicollinearity. It arises that all the OLS's criteria have been fulfilled.

\section{Results and discussion}

\subsection{Correlation analysis}

Table 2 shows the associations between different variables, which measured by the Pearson correlation coefficient. Generally, we see remarkable and significant links between market values and different independent variables $(\mathrm{p}<1 \%)$. However, there are some differences between these associations. The correlations between market values of French companies, on one hand, and earnings, book values of equity and book values of equity before intangibles, on the other hand, are significant and powerful; they attained $0.771,0.726$ and 0.657 respectively. The other correlations are significant and medium. As presented in Table 2, all associations between the different independent variables are significant and medium, what excludes any substantial effects of these associations on the relationships between dependent variable and independent variables.

\begin{tabular}{|c|c|c|c|c|c|c|c|c|c|}
\hline & $\operatorname{Ln}(\mathbf{P})$ & $\operatorname{Ln}(\mathrm{BV})$ & $\operatorname{Ln}(E)$ & $\operatorname{Ln}(\mathrm{CF})$ & $\operatorname{Ln}(\mathrm{IA})$ & $\operatorname{Ln}(\mathbf{G W})$ & $\operatorname{Ln}(\mathrm{AIC})$ & Ln(BV_IN) & $\operatorname{Ln}\left(E_{-}\right.$AIC $)$ \\
\hline $\operatorname{Ln}(\mathbf{P})$ & 1 & & & & & & & & \\
\hline $\operatorname{Ln}(\mathrm{BV})$ & $.771 * *$ & 1 & & & & & & & \\
\hline $\operatorname{Ln}(E)$ & $.726 * *$ & $.591 * *$ & 1 & & & & & & \\
\hline $\operatorname{Ln}(\mathrm{CF})$ & $.445^{* *}$ & $.535 * *$ & $.443^{* *}$ & 1 & & & & & \\
\hline Ln(IA) & $.526^{* *}$ & $.586 * *$ & $.429 * *$ & $.351 * *$ & 1 & & & & \\
\hline $\operatorname{Ln}(G W)$ & $.565^{* *}$ & $.574 * *$ & $.484^{* *}$ & $.314^{* *}$ & $.520^{* *}$ & 1 & & & \\
\hline Ln(AIC) & $.457 * *$ & $.560 * *$ & $.445^{* *}$ & $.345^{* *}$ & $.598^{* *}$ & $.548^{* *}$ & 1 & & \\
\hline Ln(BV_IN) & $.657 * *$ & & & $.463 * *$ & & & & 1 & \\
\hline $\operatorname{Ln}\left(E_{-}\right.$AIC) & $.500 * *$ & & & $.334 * *$ & & & & $.499 * *$ & 1 \\
\hline
\end{tabular}

** Correlation is significant at the 0.01 level (2-tailed).

Table 2. Correlation results 


\subsection{Value relevance of traditional accounting measures before intangibles}

Table 3 presents model (01) estimated using the yearly cross-section data and pooled data. F-stat. indicates that the cross-sectional regressions in each year and, the pooled regression in the whole period are significant. Every year, the estimates of constant $\left(\alpha_{0}\right)$ are significant and positive; they represent the company's market value when all accounting measures before intangibles take the value zero. The coefficient estimates of equity's book values before intangibles $\left(\alpha_{1}\right)$ and the coefficient estimates of earnings before amortization and impairment charges of intangibles $\left(\alpha_{2}\right)$ are significant and positive in each year, except in 2006, when the coefficient estimate of earnings before amortization and impairment charges $\left(\alpha_{2}\right)$ is not significant. However, the coefficient estimates of cash flows $\left(\alpha_{3}\right)$ are not significant in each year, except in 2008.

The pooled regression provides similar results; it shows positive and significant relationships between companies' market values, on one hand, its equity's book values before intangibles and earnings before amortization and impairment charges, on the other hand. $\alpha_{1}$ is more than $\alpha_{2}$ in each year, this means that book values of equity before intangibles are more associated with market values than earnings before amortization and impairment charges. On the contrary, the pooled regression suggests that the relationship between market values and cash flows is not significant. Finally, the coefficient of determination $\left(\mathrm{R}_{\text {TAM }}^{2}\right)$ indicates that traditional accounting measures before intangibles as a whole are value relevant; they explain an important part of market values, their explanatory power has known an increase between the beginning and the end of period.

\begin{tabular}{|c|c|c|c|c|c|c|c|c|c|c|}
\hline \multicolumn{11}{|c|}{ Model (1): $P_{i t}=\alpha_{0}+\alpha_{1} B V \_I N_{i t}+\alpha_{2} E \_A I C_{i t}+\alpha_{3} C F_{i t}+\varepsilon_{i t}$} \\
\hline \multirow{2}{*}{ Year } & \multicolumn{2}{|c|}{ Constant } & \multicolumn{2}{|c|}{ Ln(BV_IN) } & \multicolumn{2}{|c|}{$\operatorname{Ln}\left(E_{-}\right.$AIC $)$} & \multicolumn{2}{|c|}{$\operatorname{Ln}(\mathrm{CF})$} & \multirow{2}{*}{$R_{T A M}^{2}$} & \multirow{2}{*}{ F-stat. } \\
\hline & $\alpha_{0}$ & $t$ & $\alpha_{1}$ & $\boldsymbol{t}$ & $\alpha_{2}$ & $t$ & $\alpha_{3}$ & $t$ & & \\
\hline 2005 & $2.142^{* *}$ & 22.214 & $.311^{* *}$ & 6.205 & $.067 * *$ & 3.181 & .006 & .375 & $51.0 \%$ & 38.824 \\
\hline 2006 & $2.303^{* *}$ & 22.736 & $.422 * *$ & 7.860 & .021 & 1.490 & .010 & .512 & $53.7 \%$ & 42.800 \\
\hline 2007 & $2.441 * *$ & 23.760 & $.390 * *$ & 7.325 & .041 & 2.912 & .014 & .531 & $53.8 \%$ & 43.295 \\
\hline 2008 & $1.842^{* *}$ & 15.944 & $.386^{* *}$ & 5.500 & $.115^{* *}$ & 4.204 & $-.074 * *$ & -3.913 & $58.8 \%$ & 51.997 \\
\hline 2009 & $1.547 * *$ & 12.376 & $.266^{* *}$ & 4.223 & $.186^{* *}$ & 6.495 & .020 & .885 & $50.4 \%$ & 37.883 \\
\hline 2010 & $1.696^{* *}$ & 13.604 & $.546^{* *}$ & 9.781 & $.101^{* *}$ & 4.259 & .000 & .474 & $57.4 \%$ & 47.762 \\
\hline 2011 & $1.897 * *$ & 13.695 & $.467 * *$ & 6.935 & $.054 * *$ & 2.733 & -.017 & -.506 & $45.7 \%$ & 32.413 \\
\hline 2012 & $1.216 * *$ & 9.211 & $.535^{* *}$ & 7.864 & $.138^{* *}$ & 4.335 & .018 & .706 & $62.1 \%$ & 61.110 \\
\hline 2013 & $1.511 * *$ & 10.345 & $.440 * *$ & 6.707 & $.161 * *$ & 5.582 & .006 & .175 & $54.2 \%$ & 43.914 \\
\hline Panel & $1.857 * *$ & 46.133 & $.392 * *$ & 19.000 & .109 ** & 13.109 & .000 & .135 & $47.2 \%$ & 44.444 \\
\hline
\end{tabular}

** Coefficient is significant at the 0.01 level (2-tailed).

Table 3. Model (1) 
According to the results, book values of equity before intangible items and, earnings before amortization and impairment charges of intangibles can explain the variability of market values of French companies during the period; they attract the attention of investors, which view them as reliable signals for the perspective of equity valuation. Those items represent a key accounting indicators that are widely employed by financial analysts and other users in order to assess the future financial position of a company and its prospective performance. Contrariwise, cash flows do not furnish any explanation for the variability of market values of French companies during the period. Even if cash flow represents a main figure that commonly used to analyze the company liquidity and its solvency, it does not get enough attention from investors in Paris Stock Exchange, which they do not take it into consideration when they construct their decisions. This can be assigned to the high volatility of cash flows during the period, which have known random evolutions as shown in Figure 2. These fluctuations do not enable investors to assess the value of company starting of cash flows, because there is no a regular declined or increased evolution during the period.

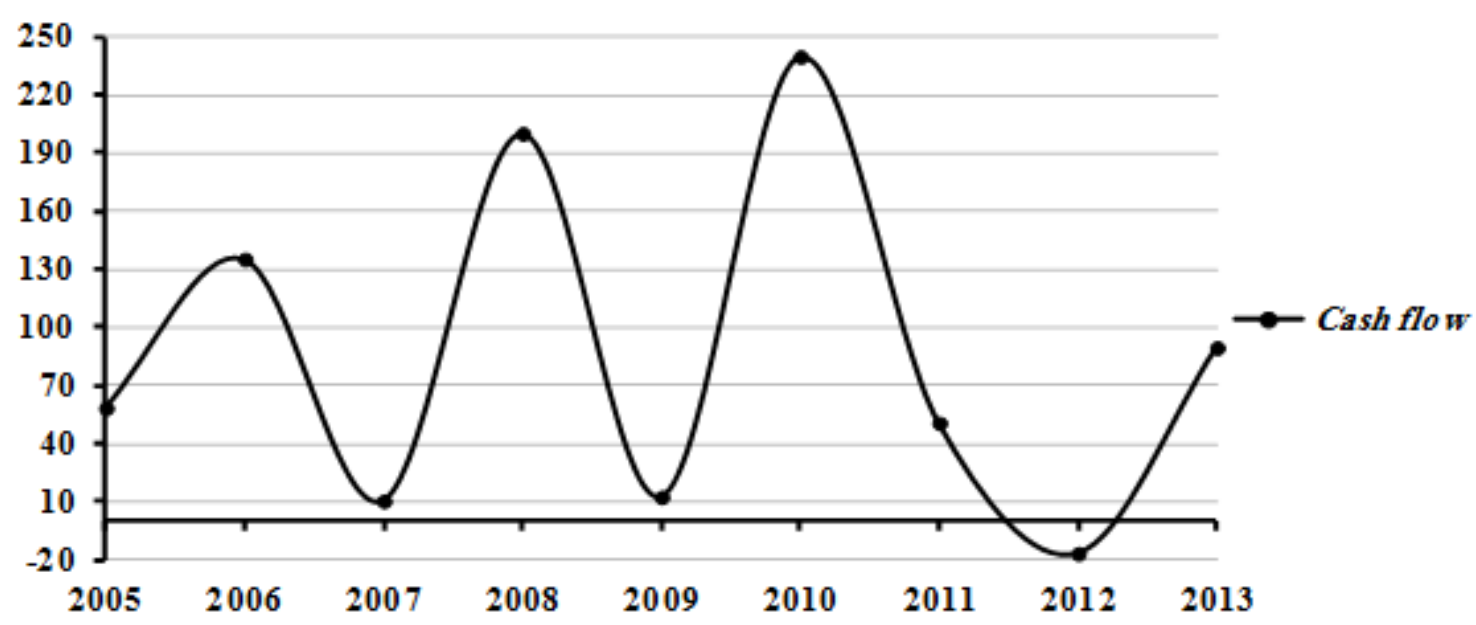

Figure 2. Cash flows of French companies (Depending on: Financial statements of companies, Euronext, Yahoo finance, Zone bourse, Xavierpaper; 2005-2013)

\subsection{Value relevance of intangibles}

Table 4 shows model (02), which represents the yearly cross-sectional regressions and pooled regression of market values of French companies on intangibles. According to F-stat., the crosssectional regressions and the pooled regression are significant. The estimates of constant $\left(\beta_{0}\right)$ are positive and significant every year; they provide estimations for market values when all intangible items take the value zero. As mentioned in Table 4, the coefficient estimates of amortization and impairment 
charges of intangible assets and goodwill $\left(\beta_{3}\right)$ are not significant every year, it is only significant when it is estimated using the panel data. This means that amortization and impairment charges of intangible assets and goodwill do not have any significant effect on the market values of French companies. Contrariwise, the coefficient estimates of both intangible assets $\left(\beta_{1}\right)$ and goodwill $\left(\beta_{2}\right)$ are positive and significant every year, they indicates positive effects of intangible assets and goodwill on market values of French companies. Except in 2005 and 2013, the coefficient estimates of goodwill are more than the coefficient estimates of intangible assets every year, what provides evidence that goodwill are more associated with market values than intangible assets. Concerning the value relevance of intangibles, the coefficients of determination $\left(R_{I N}^{2}\right)$ indicate that intangibles as a whole are value relevant and explain over $50 \%$ of market values variability every year except in 2011. Finally, we do not see many differences between the results of pooled regression and those of cross-sectional regressions.

\begin{tabular}{|c|c|c|c|c|c|c|c|c|c|c|}
\hline \multicolumn{11}{|c|}{ Model (2): $P_{i t}=\beta_{0}+\beta_{1} I A_{i t}+\beta_{2} G W_{i t}+\beta_{3} A I C_{i t}+\mu_{i t}$} \\
\hline \multirow{2}{*}{ Year } & \multicolumn{2}{|c|}{ Constant } & \multicolumn{2}{|c|}{$\operatorname{Ln}(\mathrm{IA})$} & \multicolumn{2}{|c|}{$\operatorname{Ln}(\mathrm{GW})$} & \multicolumn{2}{|c|}{$\operatorname{Ln}(\mathrm{AIC})$} & \multirow{2}{*}{$R_{I N}^{2}$} & \multirow{2}{*}{ F-stat. } \\
\hline & $\beta_{0}$ & $t$ & $\beta_{1}$ & $t$ & $\beta_{2}$ & $t$ & $\beta_{3}$ & $t$ & & \\
\hline 2005 & $2.885^{* *}$ & 21.036 & $.166^{* *}$ & 3.943 & $.153^{* *}$ & 3.034 & .010 & .160 & $34.9 \%$ & 22.668 \\
\hline 2006 & $3.124 * *$ & 21.648 & $.143^{* *}$ & 2.727 & $.165^{* *}$ & 3.727 & .021 & .319 & $32.9 \%$ & 21.742 \\
\hline 2007 & $3.009 * *$ & 17.992 & $.130^{*}$ & 2.264 & $.257 * *$ & 5.460 & -.001 & .014 & $40.1 \%$ & 0.061 \\
\hline 2008 & $2.608^{* *}$ & 18.031 & $.145^{* *}$ & 2.617 & $.308^{* *}$ & 6.989 & -.010 & -.183 & $48.2 \%$ & 41.035 \\
\hline 2009 & $1.944 * *$ & 12.481 & $.216^{* *}$ & 3.785 & $.347 * *$ & 6.330 & -.050 & -.810 & $48.0 \%$ & 41.287 \\
\hline 2010 & $2.244 * *$ & 14.387 & $.210^{* *}$ & 4.165 & $.391 * *$ & 7.176 & -.058 & -.884 & $53.0 \%$ & 48.681 \\
\hline 2011 & $2.180^{* *}$ & 13.152 & $.270^{* *}$ & 4.415 & $.373 * *$ & 7.251 & -.139 & -1.902 & $53.6 \%$ & 50.978 \\
\hline 2012 & $1.857 * *$ & 10.606 & $.272^{* *}$ & 4.756 & $.390^{* *}$ & 6.382 & -.128 & -1.867 & $48.0 \%$ & 41.078 \\
\hline 2013 & $2.350^{* *}$ & 12.764 & $.269 * *$ & 4.263 & $.251 * *$ & 4.433 & .000 & .002 & $44.4 \%$ & 36.736 \\
\hline Panel & $2.458^{* *}$ & 45.028 & $.185^{* *}$ & 9.760 & $.289 * *$ & 15.967 & $-.054 *$ & -2.381 & $39.7 \%$ & 37.141 \\
\hline
\end{tabular}

Table 4. Model (2)

The results provide evidence about the important role of intangible assets and goodwill in market values' variability. This signifies that any change in these items give rise to a change into the same direction in market values of French companies through affecting the decisions of investors in stock market, and thus, investors take into consideration intangible items that reported in balance sheet when they value securities. The increase of these items can consider as an increase in wealth of company; it can be also interpreted by investors as a perspective of wealth generation in the future, what stimulates any potential investor to pay a supplementary amount to own a part of company's equity. However, the decrease of intangible items in balance sheet operates the reverse effect as a translation of the decrease in wealth of company and its future perspectives. Concerning the amortization and impairment charges 
of intangible assets and goodwill, they do not provoke any change in market values of French companies. This can be explained through the no reliability of their amounts reported in balance sheet, which are determined depending on judgments and estimations of managers. Thence, investors do not take them into consideration when they value companies.

\subsection{Incremental value relevance of intangibles}

Table 5 summarizes model (3) which relates market values of French companies with traditional accounting measures and intangible items. As mentioned in Table 5, F-stat. demonstrates the signification of cross-sectional regressions every year and pooled regression. The constant's estimates $\left(\delta_{0}\right)$ are positive and significant every year, what furnishes approximate amounts for market values of French companies when all traditional accounting measures and intangible items take the value zero. The coefficient estimates of both book values $\left(\delta_{1}\right)$ and earnings $\left(\delta_{2}\right)$ are positive and significant in each year, except in 2005, 2006, 2009 and 2011, when the coefficient estimate of earnings ( $\left.\delta_{2}\right)$ is not significant. On the contrary, the coefficient estimate of cash flows $\left(\delta_{3}\right)$ is not significant in the most years and takes the value zero when it is estimated using panel data. Regarding intangibles, we see that the coefficient estimates of both intangible assets $\left(\delta_{4}\right)$ and amortization and impairment charges of intangibles $\left(\delta_{6}\right)$ are not significant in the most years, except in 2011, 2012 and 2013, but they are significant when they are estimated using the panel data. However, the coefficient estimates of goodwill $\left(\delta_{5}\right)$ are positive and significant in the most years (except in 2005 and 2013). When comparing Table 3 with Table 5, we observe that intangible items affect positively the relationship between market values and book values, the coefficient estimates of book values in model (03) are more than them in model (01). However, intangible items affect negatively the relationship between market values and earnings, but they do not affect the relationship between market values and cash flows. 


\begin{tabular}{|c|c|c|c|c|c|c|c|c|c|c|c|}
\hline \multicolumn{12}{|c|}{ Model (3): $P_{i t}=\delta_{0}+\delta_{1} B V_{i t}+\delta_{2} E_{i t}+\delta_{3} C F_{i t}+\delta_{4} I A_{i t}+\delta_{5} G W_{i t}+\delta_{6} A I C_{i t}+3_{i t}$} \\
\hline \multicolumn{2}{|l|}{ Year } & 2005 & 2006 & 2007 & 2008 & 2009 & 2010 & 2011 & 2012 & 2013 & Panel \\
\hline \multirow{2}{*}{ Constant } & $\delta_{0}$ & $1.995^{* *}$ & $1.919^{* *}$ & $1.951 * *$ & $1.379 * *$ & $.712^{* *}$ & $.805^{* *}$ & $.754 * *$ & $.391 *$ & $.514 * *$ & $1.064 * *$ \\
\hline & $t$ & 11.069 & 10.727 & 10.029 & 7.595 & 3.382 & 4.816 & 4.197 & 2.077 & 2.862 & 15.714 \\
\hline \multirow{2}{*}{$\operatorname{Ln}(B V)$} & $\delta_{1}$ & $.378^{* *}$ & $.428^{* *}$ & $.455^{* *}$ & $.511 * *$ & $.622 * *$ & $.733 * *$ & $.663^{* *}$ & $.643^{* *}$ & $.744^{* *}$ & $.608^{* *}$ \\
\hline & $t$ & 5.191 & 7.021 & 6.416 & 7.024 & 7.223 & 11.706 & 9.468 & 8.084 & 11.520 & 23.845 \\
\hline \multirow{2}{*}{$\operatorname{Ln}(E)$} & $\delta_{2}$ & .024 & .016 & $.035^{* *}$ & $.075^{* *}$ & .030 & $.030^{*}$ & .020 & $.101^{* *}$ & $.103^{* *}$ & $.034 * *$ \\
\hline & $t$ & 1.103 & 1.406 & 2.857 & 3.882 & 1.508 & 2.068 & 1.803 & 3.982 & 5.133 & 6.427 \\
\hline \multirow{2}{*}{$\operatorname{Ln}(C F)$} & $\delta_{3}$ & -.003 & .017 & .006 & $-.029 *$ & $.039 *$ & .000 & -.015 & .015 & $-.033^{* *}$ & .000 \\
\hline & $t$ & -.259 & 1.129 & .294 & -2.239 & 2.020 & \begin{tabular}{l|}
-.278 \\
\end{tabular} & -.930 & .999 & -3.240 & -.197 \\
\hline \multirow{2}{*}{$\operatorname{Ln}(I A)$} & $\delta_{4}$ & .021 & .050 & .046 & .047 & .080 & .034 & $.153 * *$ & $.110^{* *}$ & $.091 *$ & $.053^{* *}$ \\
\hline & $t$ & .591 & 1.225 & 1.025 & 1.173 & 1.700 & .930 & 3.331 & 2.621 & 2.195 & 3.574 \\
\hline \multirow{2}{*}{$\operatorname{Ln}(G W)$} & $\delta_{5}$ & .076 & $.093^{* *}$ & $.088^{*}$ & $.121 * *$ & $.120 *$ & $.134 * *$ & $.119 * *$ & $.126^{* *}$ & .043 & $.110^{* *}$ \\
\hline & $t$ & 1.890 & 2.629 & 2.067 & 3.470 & 2.364 & 3.084 & 2.658 & 2.611 & 1.142 & 7.361 \\
\hline \multirow{2}{*}{$\operatorname{Ln}(A I C)$} & $\delta_{6}$ & .015 & -.072 & -.025 & -.001 & -.034 & -.019 & $-.167 * *$ & $-.126^{* *}$ & -.044 & $-.067 * *$ \\
\hline & $t$ & .311 & -1.409 & -.459 & -.019 & -.661 & -.422 & -3.158 & -2.693 & -.913 & -3.903 \\
\hline \multicolumn{2}{|c|}{$R_{T A M, I N}^{2}$} & $57.6 \%$ & $61.4 \%$ & $64.3 \%$ & $75.2 \%$ & $68.9 \%$ & $79.2 \%$ & $76.1 \%$ & $76.0 \%$ & $79.5 \%$ & $67.2 \%$ \\
\hline \multicolumn{2}{|l|}{$F$-stat. } & 27.525 & 34.656 & 39.760 & 65.850 & 48.567 & 79.656 & 68.973 & 67.942 & 86.560 & 57.721 \\
\hline
\end{tabular}

** Coefficient is significant at the 0.01 level (2-tailed).

* Coefficient is significant at the 0.05 level (2-tailed).

Table 5. Model (3)

Table 6 shows the incremental value relevance of intangibles $\left(R^{2}{ }_{I N \mid T A M}\right)$ in each year and in the whole period of study, which represents the increase of value relevance of traditional accounting measures caused by intangible items. It measured by the difference between the coefficients of determination of

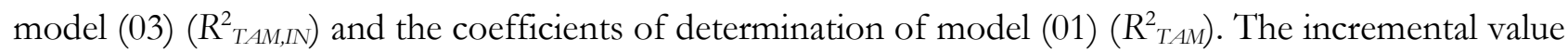
relevance of intangible items translates the role of intangibles in improving the informational content of traditional accounting measures, through providing information that confirms an earlier information or events, or through providing new information that are unknown previously, which completes the information convoyed by traditional accounting measures (Landsman \& Maydew, 2001; Dumontier, 1999).

\begin{tabular}{|l|r|r|l|l|l|l|l|l|l|c|}
\hline \multicolumn{1}{|c|}{ Year } & $\mathbf{2 0 0 5}$ & $\mathbf{2 0 0 6}$ & $\mathbf{2 0 0 7}$ & $\mathbf{2 0 0 8}$ & $\mathbf{2 0 0 9}$ & $\mathbf{2 0 1 0}$ & $\mathbf{2 0 1 1}$ & $\mathbf{2 0 1 2}$ & $\mathbf{2 0 1 3}$ & Panel \\
\hline $\mathrm{R}^{2}{ }_{T A M, I N}$ & $57.6 \%$ & $61.4 \%$ & $64.3 \%$ & $75.2 \%$ & $68.9 \%$ & $79.2 \%$ & $76.1 \%$ & $76.0 \%$ & $79.5 \%$ & $67.2 \%$ \\
\hline $\mathrm{R}^{2}{ }_{T A M}$ & $51.0 \%$ & $53.7 \%$ & $53.8 \%$ & $58.8 \%$ & $50.4 \%$ & $57.4 \%$ & $45.7 \%$ & $62.1 \%$ & $54.2 \%$ & $47.2 \%$ \\
\hline $\mathrm{R}^{2}{ }_{I N \mid T A M}$ & $6.6 \%$ & $7.7 \%$ & $10.5 \%$ & $16.4 \%$ & $18.5 \%$ & $21.8 \%$ & $30.4 \%$ & $13.9 \%$ & $25.3 \%$ & $20.0 \%$ \\
\hline
\end{tabular}

Table 6. The incremental value relevance of intangibles

Table 6 indicates that traditional accounting measures and intangibles explain the largest part of market values of French companies, $\mathrm{R}_{T A M, I N}^{2}$ is more than $60 \%$ in each year except in 2005 . The common 
value relevance of both traditional accounting measures and intangibles has known an important increase during the period. Even if the traditional accounting measures before intangibles explain an important part of market values, their explanatory power is less than their explanatory power after intangibles in each year $\left(\mathrm{R}_{T A M}^{2}<60 \%\right)$, and it decreased during the period. Finally, the incremental value relevance of intangibles $\left(R_{I N \mid T A M}^{2}\right)$ is positive every year and it has increased importantly during the period, what demonstrates that intangibles affect positively the value relevance of traditional accounting measures, and improve their power to explain market values.

These findings suggest that intangibles as a whole have incremental value relevance in the French context; they remarkably increase the value relevance of accounting information through improving their pertinence and reliability. This requires a concordance between the informational content of both intangibles and accounting information. For that, intangible items must confirm accounting information through providing the same content, or providing a new content that complete their informational content. Nevertheless, the value relevance of cash flows have not affected by intangibles, because there is no direct or indirect current effect of intangible items on cash flows. The recognition of intangible assets, their amortization and impairment, their revaluation and their derecognition do not have any effect on cash flows of company, while these treatments have an important effects on company performance and its financial position, especially in the future.

\section{Conclusion}

In this paper, we explored whether intangible items that recognised in financial statements are value relevant for investors in the French context. The intangible items have been expressed by intangible assets, goodwill and amortization and impairment charges of intangibles. Our assumptions started from the conclusions of several studies that indicated a persistent declining in the value relevance of accounting information. The explanations consented that, the rising role of intangibles conducted by the economic changes and companies' needs to manipulate and manage intangibles was one of the main causes that aggravates the declining value relevance of accounting information. In order to confirm or disclaim the aforesaid conclusions, we attempted to test the relative value relevance and the incremental value relevance of intangibles. The adopted methodology focused on verifying the links between intangible items and market values of companies and displaying the role of intangibles in explaining the market values variability. Also we verified the effect of intangibles on the links between market values and traditional accounting measures, expressed by equity's book values, earnings and cash flows. 
The study interested by the French listed companies during the period of 2005 to 2013 after the IFRS mandatory adoption by EU's listed companies. To test the value relevance of intangibles for the valuation of French companies, we have chosen randomly a sample of 151 listed companies, starting from the Paris All-Share equities available on the European Equities data base. Our methodology was based on the Multiple Linear Regression, and started from Ohlson (1995) to develop three models which have been estimated for each year and for the whole period of study, using Ordinary LeastSquares $(O L S)$, after ensuring that the OLS's criteria have been fulfilled. Hereafter, we make sure the signification of models using F-statistic. The relationships between market values of French companies and different independent variables have been verified through testing the signification of regressions coefficients using Student test, while the value relevance of accounting variables has been measured by the coefficients of determination $\left(R^{2}\right)$.

The results indicate that intangible items as a whole are value relevant. However, the amortization and impairment charges of intangibles do not affect the market values of French companies, unlike intangible assets and goodwill, which affect positively and substantially the market values of French companies. We found that goodwill is more associated with market values than intangible assets. Our evidence suggests also that traditional accounting measures as a whole are value relevant, the book values and earnings affect positively and significantly the market values of French companies, the effect of book values is more than the effect of earnings. Whereas the cash flows do not have any significant effect on the market values of French companies. Concerning the incremental value relevance of intangibles, the traditional accounting measures and intangibles jointly are shown to be more value relevant than traditional accounting measures alone, this means that intangibles have improved the value relevance of accounting information.

Generally, the study was followed the methodical procedures of several prior researches and has confirmed their results (Sougiannis, 1994; Aboody \& Lev, 1998; Zhao, 2002; Seethamraju, 2003; Goodwin \& Ahmed, 2006). Our research design has been based on Ohlson's (1995) model in order to test the incremental association of intangibles in a regression of equities' market values on accounting information over a long period. Our findings have proved the role of intangibles in explaining the companies' market values and improving the explanatory power of other accounting information (Cazavan-Jeny \& Jeanjean, 2003; Lenormand \& Touchais, 2008; Loulou \& Triki, 2008; Boulerne \& Sahut, 2009). However, we addressed some differences between our study and the prior researches. First, we have converted the variables amounts obtained from the financial statements into their logarithmic counterparts. Second, we improved the measure of incremental value relevance by 
measuring the value relevance of accounting information after eliminating the effect of intangible items. For that, we have subtracted intangible assets and goodwill from the book values of equity and added the amortization and impairment charges of intangibles to the earnings. Finally, unlike several prior researches which found a declining value relevance of accounting information (Lev \& Zarowin, 1999; Brown et al., 1999; Graham et al., 2000; Black \& White, 2003; Dontoh et al., 2007), or which suggested that intangibles are not value relevant (Thibierge, 2001; Ding \& Stolowy, 2003; Cazavan-Jeny, 2003; Casta \& Ramond, 2005; Jamoussi et al., 2007), we have observed an increasing value relevance of intangibles and other accounting variables, except of the cash flows and the amortization and impairment charges of intangibles.

\section{References}

Aboody, D., \& Lev, B. (1998). The value relevance of intangibles: The case of Software capitalization. Journal of Accounting Research, 36, 161-191. http://dx.doi.org/10.2307/2491312

Balachandran, S., \& Mohanram, P. (2011). Is the decline in the value relevance of accounting driven by increased conservatism?. Review of Accounting Studies, 16(02), 272-301. http://dx.doi.org/10.1007/s11142010-9137-0

Barth, M.E., Beaver, W.H., \& Landsman, W.R. (2001). The relevance of the value relevance literature for financial accounting standard setting: Another view. Journal of Accounting and Economics, 31, 77-104. http://dx.doi.org/10.1016/S0165-4101(01)00019-2

Beisland, L.A. (2009). A Review of the Value Relevance Literature. The Open Business Journal, 02, 07-27. http://dx.doi.org/10.2174/1874915100902010007

Black, E.L., \& White, J.J. (2003). An international comparison of income statement and balance sheet information: Germany, Japan and the US. European Accounting Review, 12(01), 29-46. http://dx.doi.org/10.1080/0963818022000001127

Boulerne, S., \& Sahut, J.M. (2009). Have IFRS improved the information content of intangibles?: The case of French listed companies. The 32nd Annual Congress of the European Accounting Association, Tampere (Finland).

Brown, S., Lo, K., \& Lys, T. (1999). Use of R2 in accounting research: Measuring changes in value relevance over the last four decades. Journal of Accounting and Economics, 28, 83-115. http://dx.doi.org/10.1016/S0165-4101(99)00023-3 
Cañibano, L., García-Ayuso, M., \& Sánchez, P. (2000). Accounting for Intangibles: A literature review. Journal of Accounting Literature, 19, 102-130.

Casta, J.F., \& Ramond, O. (2005). Investissement en capital immatériel et utilité de l'information comptable: Étude comparative des marchés financiers britannique, espagnol et français. Cahier de recherche n²005-07 CEREG Université Paris - Dauphine, France.

Cazavan-Jeny, A. (2003). Value-relevance of expensed and capitalized intangibles - Empirical evidence from France. Working Paper DR 03022 ESSEC, France.

Cazavan-Jeny, A., \& Jeanjean, T. (2003). Value Relevance of R®D reporting: A Signalling Interpretation. Working paper 2003-12 CEREG University Paris IX Dauphine, France.

Chalmers, K., Clinch, G., \& Godfrey, J.M. (2011). Changes in value relevance of accounting information upon IFRS adoption: Evidence from Australia. Australian Journal of Management, 36(02), 151-173. http://dx.doi.org/10.1177/0312896211404571

Cohen, J.A. (2005). Intangible Assets V aluation and Economic Benefit. New Jersey: John Wiley \& Sons.

Collins, D.W., Maydew, E.L., \& Weiss, I.S. (1997). Changes in the value-relevance of earnings and book values over the past forty years. Journal of Accounting and Economics, 24, 39-67. http://dx.doi.org/10.1016/S0165-4101(97)00015-3

Córcoles, Y.R. (2010). Towards the convergence of accounting treatment for intangible assets. Intangible Capital, 06(02), 185-201.

Dahmash, F.N., \& Qabajeh, M. (2012). Value Relevance of Ohlson Model with Jordanian Data. Interdisciplinary Journal of Contemporary Research in Business, 03(11), 551-560.

Daum, J.H. (2003). Intangible Assets and V alue Creation. England: John Wiley \& Sons.

Ding, Y., \& Stolowy, H. (2003). Capitalisation des frais de R\&D en France: Déterminants et pertinence. 24e congrès de l'AFC - Identification et maîtrise des risques: enjeux pour l'audit, la comptabilité et le contrôle de gestion, France.

Dontoh, A., Radhakrishnan, S., \& Ronen, J. (2007). Is stock price a good measure for assessing valuerelevance of earnings?. An empirical test. Review of Managerial Science, 01(01), 03-45

Dumontier, P. (1999). Information comptable et création de valeur: Le cours de bourse ne suffit pas. Revue française de gestion: 122, 99-105. http://dx.doi.org/10.1080/096381898336439

Dumontier, P., \& Labelle, R. (1998). Accounting earnings and firm valuation: The French case. European Accounting Review, 07(02), 163-183. 
Eckstein, C. (2004). The measurement and recognition of intangible assets: Then and now. Accounting Forum, 28, 139-158. http://dx.doi.org/10.1016/j.accfor.2004.02.001

Ely, K., \& Waymire, G. (1999). Intangible Assets and Stock Prices in the Pre-SEC Era. Journal of Accounting Research, 37, 16-44. http://dx.doi.org/10.2307/2491343

Ernst \& Young (2008). Capital immatériel, son importance se confirme. Available online at: http://www.ey.com/Publication/vwLUAssets/0108_Etude_Capital_Immateriel/ $\$$ file/0108 Etude Capital Immateriel.pdf (Last access date: May, 2014).

Fustec, A. (2011). Thésaurus-Bercy V1: Référentiel Français de mesure de la valeur extra-financière et financière du capital immatériel des entreprises. France: Ministère français de l'économie, des finances et de l'industrie.

Francis, J., \& Schipper, K. (1999). Have Financial Statements Lost their Relevance?. Journal of Accounting Research, 37(02), 319-352. http://dx.doi.org/10.2307/2491412

Gjerde, Ø., Knivsflå, K., \& Sættem, F. (2011). The value relevance of financial reporting in Norway 1965-2004. Scandinavian Journal of Management, 27, 113-128. http://dx.doi.org/10.1016/j.scaman.2010.08.001

Glezakos, M., Mylonakis, J., \& Kafouros, C. (2012). The Impact of Accounting Information on Stock Prices: Evidence from the Athens Stock Exchange. International Journal of Economics and Finance, 04(02), 56-68. http://dx.doi.org/10.5539/ijef.v4n2p56

Goodwin J., \& Ahmed, K. (2006). Longitudinal value relevance of earnings and intangible assets: Evidence from Australian firms. Journal of International Accounting, Auditing and Taxation, 15, 72-91. http://dx.doi.org/10.1016/j.intaccaudtax.2006.01.005

Graham, R., King, R., \& Bailes, J. (2000). The Value of Accounting: Information during a Financial Crisis: Thailand and the 1997 Decline in the Value of the Baht. Journal of International Financial Management and Accounting, 11(02), 84-107. http://dx.doi.org/10.1111/1467-646X.00057

Hail, L. (2013). Financial Reporting and Firm Valuation: Relevance Lost or Relevance Regained?. Accounting and Business Research, 43(04), 329-358. http://dx.doi.org/10.1080/00014788.2013.799402

IASB (1989). Framework for the Preparation and Presentation of Financial Statements.

IASB (2004). LAS 38: Intangible Assets.

IASB (2008). IFRS 03: Business Combinations.

Jaafar, H. (2010). Accounting Choice, Firm Life-Cycle and the Value-Relevance of Intangible Assets. Global Review of Accounting and Finance, 01(01), 18-40. 
Jamoussi, W., Baklouti, M.A., \& Affes, H. (2007). La pertinence des intangibles dans l'évaluation des entreprises: Cas du marché français. 28e Congrès de l'association Francophone de Comptabilité, comptabilité et environnement, Poitiers (France).

Karğın, S. (2013). The Impact of IFRS on the Value Relevance of Accounting Information: Evidence from Turkish Firms. International Journal of Economics and Finance, 05(04), 71-80. http://dx.doi.org/10.5539/ijef.v5n4p71

Lam, K.C.K., Sami, H., \& Zhou, H. (2013). Changes in the value relevance of accounting information over time: Evidence from the emerging market of China. Journal of Contemporary Accounting \& Economics, 9(2), 123-135. http://dx.doi.org/10.1016/j.jcae.2013.06.001

Landsman W.R., \& Maydew E.L. (2001). Beaver (1968) Revisited: Has the Information Content of Quarterly Earnings Announcements Declined in the Past Three Decades?. SSRN Electronic Journal 05/2001. http://dx.doi.org/10.2139/ssrn.204068

Lasteyrie, R. (2011). Présentation du 5e Profil financier du CAC 40. Available online at: http://www.ricollasteyrie.fr/doc/news/2011/Com\%205eme\%20Profil $\% 20 \mathrm{CAC} \% 2040 \% 20 \% 20 \mathrm{DEF}$.pdf (Last access date: June, 2014).

Lenormand, G., \& Touchais, L. (2008). La pertinence des actifs incorporels avec les IFRS. Finance Contrôle Stratégie, 11(02), 173-201.

Lev, B. (1989). On the usefulness of earnings and earnings research: Lessons and directions from two decades of empirical research. Journal Accounting Research, 27, 153-192. http://dx.doi.org/10.2307/2491070

Lev, B. (2001). Intangibles: Management, Measurement, and Reporting. Washington: Brookings Institution.

Lev, B., \& Zarowin, P. (1999). The Boundaries of Financial Reporting and How to Extend Them. Journal of Applied Corporate Finance, 37(02), 353-385. http://dx.doi.org/10.2307/2491413

Loulou, S., \& Triki, M. (2008). Déterminants et pertinence de l'activation des dépenses de recherche and développement dans le contexte des entreprises françaises. The $29 e$ congrès de l'AFC - La comptabilité, le contrôle et l'audit entre changement et stabilité, France.

Moore, L., \& Craig, L. (2008). Intellectual Capital in Enterprise Success: Strategy Revisited. New Jersey: John Wiley \& Sons.

Nayeri, M.D., Ghayoumi, A.F., \& Bidari, M.A. (2012). Factors Affecting the Value Relevance of Accounting Information. International Journal of Academic Research in Accounting, Finance and Management Sciences, 02(02), 76-84. 
Ohlson, J.A. (1995). Earnings, book values and dividends in equity valuation. Contemporary Accounting Research, 11(02), 661-687. http://dx.doi.org/10.1111/j.1911-3846.1995.tb00461.x

Sahut, J.M., Boulerne, S., \& Frédéric, T. (2011). Do IFRS provide better information about intangibles in Europe. Review of Accounting and Finance, 10(03), 267-290. http://dx.doi.org/10.1108/14757701111155798

Seethamraju, C. (2003). The value relevance of trademarks. In B. Lev \& J. Hand (Eds.), Intangible assets: Values, measures and risks. New York: Oxford University Press.

Skinner, D.J. (2008). Accounting for intangibles - a critical review of policy recommendations. Accounting and Business Research, 38(03), 191-204. http://dx.doi.org/10.1080/00014788.2008.9663332

Sougiannis, T. (1994). The accounting based valuation of corporate R\&D. The Accounting Review, 69(01), 44-68.

The World Bank (2006). Where is the wealth of Nations? Measuring Capital for the 21st Century. Washington: The World Bank.

Thibierge, C. (2001). Actifs immatériels, valorisation boursière et contrainte d'endettement: Étude empirique sur les marchés français et espagnol. 18e Journées Internationales de l'Association Française de Finance (AFFI), Belgium.

Watts, R.L., \& Zimmerman, J.L. (1990). Positive Accounting Theory: A Ten Year Perspective. The Accounting Review, 65(01), 131-156.

Zéghal, D., \& Maaloul, A. (2011). The accounting treatment of intangibles - A critical review of the Literature. Accounting Forum, 35, 262-274. http://dx.doi.org/10.1016/j.accfor.2011.04.003

Zhao, R. (2002). Relative Value Relevance of R\&D Reporting: An International Comparison. Journal of International Financial Management and Accounting, 13(02), 153-174. http://dx.doi.org/10.1111/1467646X.00082

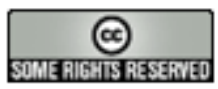

Article's contents are provided on an Attribution-Non Commercial 3.0 Creative commons license. Readers are allowed to copy, distribute and communicate article's contents, provided the author's and Intangible Capital's names are included. It must not be used for commercial purposes. To see the complete license contents, please visit http://creativecommons.org/licenses/by-nc/3.0/. 